\title{
A Work on Population Explosion
}

\author{
R. Ramamoorthy, J Pavithra, P. TamilSelvam
}

\begin{abstract}
The speedy expansion of human masses is putting a remarkable strain on our condition. While made nations keep sullying nature and exhaust its advantages, making nations are under stretching out strain to battle fiscally and their bleeding edge sorts of advancement are harming as well. The requesting that this improvement puts on our general condition are exchanging off the conceivable fate of useful life on earth. One of the best natural impacts of human individuals progression is the issue of an unsafe ecological devation. A few researchers dread that an unnatural environmental change will incite rising ocean levels and preposterous climate conditions later on. So as to help the making masses, woods are being decimated at an irritating rate. People besides keep putting an astounding excitement on the essential assets of our planet. Different non-reasonable assets are being drained because of the unbelievable utilization of fuel and significance. Different bits of the world moreover experience the shrewd effects of an insufficiency of sustenance and water. The improvement of individuals puts more prominent requests on our definitively obliged assets. Nature on earth is experiencing the improvement of generally individuals. The use of advantages and biodiversity, the generation of waste, and the devastating of regular typical surroundings are totally significant issues that must be would in general so as to guarantee that life on earth will be reasonable all through the following century.
\end{abstract}

Keywords: Industrial advancements, Land and soil degradation, global warming, Climate change

\section{INTRODUCTION}

Populace Explosion characterized as countless individuals remaining in the individual region. It is an enormous issue in India. Truth be told, in everywhere throughout the world, it is expanding, particularly in the less fortunate nations it is creating[1],[3],[5].

During the 1951 Census, the Population expanded by 361 billion. During the 2011 Census, the Population expanded by 1.21 billion.Population Explosion is a major issue in the creating nation. Nobody individuals are following the correct advance to control the Population, even the administration of India isn't driving legitimate principles and guideline for control the Population Explosion. It causes numerous issues among individuals[2 ],[4],[6].

A few people are experiencing an issue which creates by Population Explosion. Right off the bat, on this issue

Revised Manuscript Received on July 22, 2019.

R. Ramamoorthy, Department of MBA, Bharath Institute of Higher Education and Research, Chennai, India.

Email: ramamoorthy0071@gmail.com

Ms J Pavithra, Department of MBA, Bharath Institute of Higher Education and Research, Chennai, India.

Email: pavithralect@yahoo.com

P. TamilSelvam, Department of MBA, Bharath Institute of Higher Education and Research, Chennai, India

Email: tamilselvam657@gmail.com individuals are jobless, and absence of education likewise makes in India. The business development isn't actualizing in India for advancement.

\section{OBJECTIVES OF THE STUDY}

One of the impressive issues which gaze us in the appearances, is our fast expanding populace, which counterbalances each undertaking for improvement. A need is being felt for conferring accurate learning about populace dynamic, with the goal that the more youthful age may comprehend the nature and extent of the weight forced by quick populace development[7],[9],[11].

Our populace is expanding yearly at a fast pace of 2.5 percent India is beside China, has minimal less then multiple times the number of inhabitants in U.S.A., twenty-one times the number of inhabitants in Canada and in excess of multiple times the number of inhabitants in Japan. With the present development rate the nation's populace may arrive at the mind blowing figure of one-billion preceding the finish of this century[8],[10],[12].

\section{RESEARCH METHODOLOGY}

The Inflation-Deflation Method

The accomplice part strategy portrayed above necessitates that the base populace age dispersion watch the major trait that birth partners are influenced uniquely by mortality and movement as they age. The populace universe determined by the assessments base populace does not watch this basic prerequisite for two remarkable reasons. To start with, the universe reflects underenumeration of the populace at specific ages[13], [15],[17]. Second, the misquote of year of birth in the registration causes false inconsistencies in the age dispersion, particularly "storing" on certain terminal digits. On the off chance that we didn't utilize the swelling flattening technique, the utilization of the associate segment strategy would have the impact of propelling the age example of these abnormalities after some time, rendering age bunches uncomparable starting with one year then onto the next.

The swelling emptying technique is a strategy intended to beat this issue. It very well may be condensed in six stages, every one of which is completed for each sex, race, Hispanic root, and nativity classification.

\section{RESULTS AND DISCUSSIONS}

1) An elective base populace universe, that is considered to wipe out, or if nothing else limit the depicted abnormalities in the age dissemination, is used as a base populace for accomplice

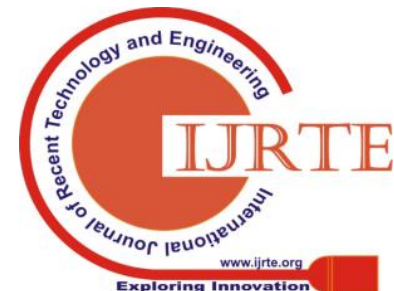


part projections. The populace utilized here, known as a Demographic Analysis Population (DA populace), is created from an amalgam of recorded information on births, passings,

and relocation for a long time under 65 , and a populace of Medicare enrollees for a very long time 65 and over. The reference date for this populace is April 1, 1990.9 [14],[16], [18]

2) An "expansion flattening factor" is processed for each single-year age gathering, as the proportion of the assessments base populace to the DA populace in that gathering, both as of April 1, 1990. The subsequent components might be not exactly or more noteworthy than one, despite the fact that they are bound to be short of what one, in light of the fact that the net impact of statistics underenumeration, enumeration duplication, age storing, and inconsistencies in racial order are bound to be negative than positive[19],[21],[23].

3) The DA populace by age is refreshed from April 1, 1990 to January 1, 1999, at that point anticipated to future dates, by the associate part technique, per conditions (2) and (3), as portrayed prior. Births, passings, and outside conceived travelers by age are inferred by use of rates, to be talked about in the following area.

4) The populace in each age gathering is increased by the expansion emptying factor for the gathering, for every quarterly reference date. While the variables are characterized for entire year age gatherings, they are thought to be steady crosswise over quarter-year ages inside the entire year gatherings.

5) The genuine base populace for the projections, the evaluations base universe, is anticipated utilizing the basic part strategy without conveyance by age, per condition (1) portrayed prior. The all out number of births, passings, and outside conceived migrants from January 1, 1999, forward are those inferred in stage 3), with results summed crosswise over age gatherings. Since the quantity of births is viewed as balanced for underregistration, births are decreased by a factor to reflect what might really be enrolled. The parity of the relocation segments are inferred numerically by means of the projection suspicions, to be talked about later in this report[20],[22], [24].

6) An expert rata change is utilized to constrain the age circulations from stage 4) to coordinate the populace aggregates from step

\section{V.CONCLUSION}

Advanced Marketing gives moment results. The motive behind why d-promotion has turned out to be so mainstream is because it gives prospective customers three notable benefits[25],[27],[29]. They are:
Comfort: No matter where they are, customers can arrange items 24 hours a day. They don't have to drive in rush hour gridlock, lack of parking place, and walk through group to find and evaluate products in incalculable stores.

Data: Without leaving their office or home, customers can find a lot of close information about organisations, items, contenders, and expenses[31],[33].

Less Hassles: Customers don't have to confront sales reps or open up to influencing and exciting variables; they don't have to keep up in line as well.

\section{REFERENCES}

1) BharthVajan R., Ramachandran S.,Psychographic dimensions of training,2016,International Journal of Pharmacy and Technology,V-8,I-4,P-23727-23729

2) Balakrishnan P., Bharthvajan R.,A study on human resource planning in hospitals in Chennai City,2014,International Journal of Applied Engineering Research,V-9,I-22,P-7503-7507

3) Priyadarsini P., Bharthvajan R.,Role of emotional intelligence training programme in reducing the stress of the nurses,2014,International Journal of Applied Engineering Research,V-9,I-22,P-7411-7421

4) Kerinab Beenu G., Bharthvajan R.,Empirical analysis on the cosmetic buying behavior of young women in South India,2014,International Journal of Applied Engineering Research,V-9,I-22,P-7361-7366

5) Balakrishnan P., Bharthvajan R.,Whistling in the wind,2014,International Journal of Applied Engineering Research,V-9,I-22,P-7586-7593

6) Krishnan B., Peter M.,Health hazards of Indian Bpo employee-an alarming issue,2014,International Journal of Applied Engineering Research,V-9,I-22,P-7336-7341

7) Kerinab Beenu G.H., Peter M.,Role of insurance in economic development,2014,International Journal of Applied Engineering Research,V-9,I-22,P-7532-7539

8) Balakrishnan P., Peter M., Priyadarsini P.,Efficiency of safety measures for wellbeing of employees in manufacturing industry,2014,International Journal of Applied Engineering Research,V-9,I-22,P-7376-7382

9) Anbarasi M., Praveen Kumar S.,Online sales promotions of herbal products and its effectiveness towards tanisha.com,2019,Indian Journal of Public Health Research and Development,V-10,I-1,P-195-200

10) Anbarasi M., Praveen Kumar S.,Various online marketing and promotions strategies to improve the validation towards the organic products in the pharmaceutical sectors,2019,Indian Journal of Public Health Research and Development,V-10,I-1,P-263-269

11) Loganathan R., Praveen Kumar S.,Grievance handling a key factor for solving issues of employees in an organization,2014,International Journal of Applied Engineering Research,V-9,I-22,P-7483-7491

12) Loganathan R., Praveen Kumar S.,Study on preference of private label brands in super and Hypermarkets,2014,International Journal of Applied Engineering Research,V-9,I-22,P-7327-7335

13) Smitha M., Praveen Kumar S.,Understanding stress and its managementamong the nurses in Chennai city,2014,International Journal of Applied Engineering Research,V-9,I-22,P-7560-7565

14) Kerinab Beenu G.H., Praveen Kumar S.,A study on the investment behavior of Chennai investors in mutual fund schemes,2014,International Journal of Applied Engineering Research,V-9,I-22,P-7520-7525

15) Loganathan R., Praveen Kumar S.,Retention strategies key for organizational productivity,2014,International Journal of Applied Engineering Research,V-9,I-22,P-7443-7447

16) Pavithra J., Ganesan M., Brindha G.,State wise analysis of microfinance sector in India,2016,International Journal of Pharmacy and Technology,V-8,I-4,P-23417-23432

17) Pavithra J., Ganesan M.,A comparative study on microfinance in India and abroad,2016,International Journal of Applied Business and Economic Research,V-14,I-8,P-5471-5476

18) Pavithra J., Ganesan M.,A study on awareness and impact of micro-financial schemes,2016,International Journal of Applied Business and Economic Research,V-14,I-8,P-5449-5460

19) Senthilmurugan P., Pavithra J.,Consumer preference towards organised retailing with reference to Big Bazaar,2014,International Journal of Applied Engineering Research,V-9,I-22,P-7469-7475

20) Senthilmurugan P., Pavithra J.,Implication of social media marketing in growing healthcare industry,2014,International Journal of Applied Engineering Research,V-9,I-22,P-7448-7456

21) Loganathan R., Pavithra J.,Consumer perception towards private label brand over other brands 
in super markets and hypermarkets,2014,International Journal of Applied Engineering Research,V-9,I-22,P-7355-7360

22) Kerinab Beenu G., Pavithra J.,Tradeâ€"off between liquidity and profitability in logistics industry,2014,International Journal of Applied Engineering Research,V-9,I-22,P-7398-7401

23) Kerinab Beenu G., Pavithra J.,A study on the prospective consumerâ€ $€^{\mathrm{TM}_{\mathrm{S}}}$ perception towards utility cars in Chennai city,2014,International Journal of Applied Engineering Research,V-9,I-22,P-7526-7531

24) Pavithra J., Dilli Babu P., Ambuli T.V.,A study on budgetary control at Maruti Service Masters, Chennai,2014,International Journal of Applied Business and Economic Research,V-12,I-2,P-151-161

25) Pavithra J., Dilli Babu P., Ambuli T.V.,A study on customer satisfaction of retro Garments Pvt Ltd, Chennai,2014,International Journal of Applied Business and Economic Research,V-12,I-2,P-381-391

26) Kerinab Beenu G.H., Pavithra J., Senthilmurugan P.,A study on the influence of promotional activities for TATA ARIA among consumers in Chennai,2014,International Journal of Applied Engineering Research,V-9,I-22,P-7572-7578

27) Vijayaragavan S.P.,An investigative expert that's general FBG sensors,International Journal of Mechanical Engineering and Technology,V-8,I-8,PP-1500-1505,Y-2017

28) Vijayaragavan S.P.,Equalization routing protocol for $\mathrm{Wi}-\mathrm{Fi}$ sensor strategy,International Journal of Mechanical Engineering and Technology,V-8,I-8,PP-1662-1666,Y-2017

29) Karthik B., Kiran Kumar T.V.U., Vijayaragavan P., Bharath Kumaran E.,Design of a digital PLL using 0.35 $\hat{\mathrm{I}}^{1 / 4 \mathrm{~m}} \mathrm{CMOS}$ technology,Middle East Journal of Scientific Research,V-18,I-12,PP-1803-1806,Y-2013

30) Kanniga E., Selvaramarathnam K., Sundararajan M.,Kandigital bike operating system,Middle - East Journal of Scientific Research,V

31) Jasmin M., Vigneshwaran T., Beulah Hemalatha S.,Design of power aware on chip embedded memory based FSM encoding in FPGA,International Journal of Applied Engineering Research,V-10,I-2,PP-4487-4496,Y-2015

32) Jasmin M.,Optimization techniques for low power VLSI circuits,Middle East Journal of Scientific Research,V-20,I-9,PP-1082-1087,Y-2014

33) Jasmin M., Vigneswaran T.,Fuzzy controller for error control of on - Chip communication,2017 International Conference on Algorithms, Methodology, Models and Applications in Emerging Technologies, ICAMMAET 2017,V-2017-January,I-,PP-1-5,Y-2017

\section{AUTHORS PROFILE}

R. Ramamoorthy Assistant Professor, Department of MBA, Bharath Institute of Higher Education and Research, Chennai, India.

Ms J Pavithra Assistant Professor, Department of MBA, Bharath Institute of Higher Education and Research, Chennai, India.

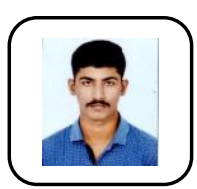

P.TamilSelvam Student, Department of MBA, Bharath Institute of Higher Education and Research, Chennai, India. 